\title{
Editorial
}

\section{Making the (Hinkley) Point about Compatibility Control}

We are living through extraordinary times and not only in the area of State aid control. It seems aeons ago that the new Commission announced its intention of better coordinating its State aid policy with its industrial and environmental policies. We have seen since then the geographically asymmetrical - granting of huge volumes of State aid linked with the Covid-19 pandemic under the coverage of the Temporary Framework. The new EU Next Generation Funds will contribute to the response by triggering, among other instruments, State aid that aims at the objectives of the green and digital agendas. At the same time, we are awakening, thanks to the consultation launched by the Commission, to the problems caused by third countries granting aid that may have a serious impact in the European Union. The State aid provisions in the recent Agreement with the United Kingdom add a new layer of complexity to an already complex situation. In only a few months, the State aid landscape has changed profoundly.

As a result, an evolution of State aid law is not only desirable but also unavoidable. The Commission is showing remarkable flexibility and creativity in this difficult context, avoiding being overwhelmed by the reality. This can only be welcomed. However, given the simultaneous presence of various significant shocks, one should not take for granted that everything is going to work well for State aid law. Indeed, keeping in place a credible control system is not only a task for the Commission but for all of us.

In order to do so, we should start with the obvious: reminding ourselves - and others - why we have a system of State aid control in the EU. Indeed, as our readers know well, Article 107(1) TFEU prohibits in principle the granting of aid. The Treaty however empowers the Commission with the possibility of declaring certain aids compatible. Such authorisation requires an analysis of the positive effects of the aid versus its negative effects for competition in the internal market, the so-called balancing test.

However, even if the above is well known in theory, its logical implications often have in fact been forgotten. The focus of the compatibility analysis has been put in recent years on the positive effects of the certain kinds of aid. The range of allegedly positive objectives has also been expanded; from the equity goals identified in the Treaty to the correction of market failures and now also to things like increasing the competitiveness of European players. It is indeed undeniable that State aid may be an effective instrument in order to attain certain positive public policy objectives pursued by the granting authority. However, this is only part of the story.

The other side of the story is that exactly the same aid that brings certain benefits is also likely to have negative effects. By definition, aid always causes a distortion in the market by changing the outcome: this would therefore always benefit some undertakings while damaging others. This change is indeed the very object of the aid. The problem is that the positive effects are normally confined to the territory of the Member State granting the aid while the negative consequences are likely to affect mainly undertakings located in other Member States. The granting authority is supposed to be aware of the expected positive effects of the aid on 
its economy; however, the said authority may not feel particularly worried about its negative externalities in other countries. However, an analysis of compatibility that would only look at the positive effects of the aid would be incomplete and, in our opinion, would make little sense. That is why the Treaty entrusted a supranational institution like the European Commission with the task of balancing both sides of the equation and deciding on compatibility.

The logical but unavoidable consequence of the above is that, in its analysis of compatibility of the aid, the Commission must necessarily consider both the positive and the negative effects. It cannot limit itself to the positive side of the equation only. If it did, it would not be undertaking any balancing exercise since, by definition, a balance has two sides.

We all know, however, that there was a growing tendency in recent years to emphasize above all the analysis of the positive effects of the aid. The Commission favours the granting of aid aimed at certain positive objectives - environmental, for instance - and adapts its guidelines in order to facilitate Member States granting such kinds of 'good aid'. Once the objective of the aid is considered 'good', its negative consequences are not paid much attention. In a way, the Commission is using its State aid powers as leverage for supporting other policies (like the environment). In doing so, it is de facto moving towards a gentle harmonisation of State aid, telling the Member States which objectives they can and cannot pursue with State aid. We must recognize that this tendency has not been particularly controversial with the Member States themselves.

The problem with this approach arises when the Commission forgets that, when it comes to State aid, its main role is a different one and it includes controlling the negative effects on competition. Indeed, a State aid may aim at a very positive objective, achieve it efficiently and - at the same time - cause a severe distortion in competition in the internal market. From the point of view of a competitor of the beneficiary, the so-called 'good aid' may indeed be much more distortive than an old-fashioned inefficient aid aimed at bad policy objectives. So, from the point of view of competition alone, a focus on the positive effects of the aid does not make much sense.

This becomes even more obvious when we think of allegedly 'good aid' granted by third country governments (China, USA, now the UK...) to their undertakings. From the point of view of European undertakings, the fact that such aid to its competitors pursues efficiently certain worthy objectives (R\&D\&I, green, digital or otherwise) is not a reason for joy but rather a matter of great concern. It goes without saying that the European interest must necessarily focus, above all, on the negative effects of such aid on competition. It would be simply suicidal to sacrifice those in view of the positive impact on other policy objectives.

The same tension also exists - albeit in a less obvious form - within the European internal market. State aid granted to a competitor is always bad news for an undertaking. The 'good' objective pursued by the authority granting the aid provides little consolation in this respect. Of course, this cannot mean that all aid shall necessarily be prohibited. It only means that the Commission must balance two legitimate goals: the one pursued by the Member State granting the aid versus the maintenance of competition in the internal market, which is the Commission's main remit. Speaking of 'balancing' implies that no side would entirely prevail.

The recent judgment of the Court of Justice of the European Union adopted in September 2020 in the Hinkley Point appeal provides a timely reminder of the above points. ${ }^{1}$ The case

1 Case C-594/18 P Austria v Commission (Hinkley Point) [2020] ECLI:EU:C:2020:742. 
refers to a long-term financial support scheme granted by the United Kingdom - when it was still an EU Member State - to the undertaking building a new nuclear power station in the English Somerset region. The Commission declared the aid compatible in 2014 after looking carefully at both the positive contribution to security of energy supply in the UK and its impact on competition in the energy market. ${ }^{2}$ In a rather unusual move, Austria challenged the said approval before the General Court by invoking the Commission's alleged failure to take into account the environmental objectives of the European Union. Other Member States also stepped in in support of either position. The General Court however endorsed in 2018 the validity of the Decision. ${ }^{3}$ The Court of Justice has now confirmed this judgment.

In a nutshell, the 2020 Hinkley Point judgment confirms that, in the balancing of positive and negative effects, one must look at both and not only at the former. The positive effects are those pursed by the Member State - here, the security of energy supply. Other objectives externally decided by European institutions - like the environmental objectives invoked by Austria - are not relevant. The negative effects are only the distortions of competition in the internal market, which must be carefully analysed and cannot certainly be minimised or ignored. Since the 2014 Commission Decision in Hinkley Point contained an unusually detailed analysis of the competitive impact of the aid, the Court validated it.

It was therefore an important judicial victory for the European Commission and for the United Kingdom, at least on the face of it. This victory may however bring some collateral damage to the winners. It is not obvious that, in its new role as third country, the UK would now appreciate the emphasis on the negative effects in competition. On its side, the Commission has recently announced its intention to use State aid control as an instrument to implement the European Green Deal, by facilitating the granting of aid for environmental objectives and by making the approval of other State aid conditional on the respect of environmental objectives. This latter idea may sound as politically correct but seems directly contradictory to the main lessons of the recent Hinkley Point judgment. Quite on the contrary, it would be another turn of the screw towards the harmonisation of national State aid policies, something that, as the Court has reminded us, is not really an EU competence.

The point made in Hinkley Point makes total sense to us. It is time for the Commission to seriously reinforce its analysis of the negative effects of the aid, as it reinforced in recent years the analysis of the positive side. EU State aid control is different from national State aid policies and the Commission should not mix both. State aid control belongs to competition law because its main objective is to care about competition. This can only reinforce the historical role of DG Competition in implementing Article 107 TFEU.

José Luis Buendía Sierra*

2 Decision 2015/658/EU of 8 October 2014, on the aid measure SA.34945 (2013/C, ex 2013/N) that the United Kingdom is planning to implement for support to the Hinkley Point C nuclear power station [2015] OJ L 109/44.

3 Case T-356/15 Austria v Commission (Hinkley Point) [2018] ECLI:EU:T:2018:439.

* José Luis Buendía Sierra is partner at Guarrigues, Brussels, and co-managing editor of EStAL. 